\title{
Age Related Changes of Human Uterus-A Postmortem Study
}

\author{
Uddin $\mathrm{MS}^{1}$, Muhaimin $\mathrm{MA}^{2}$, Begum N ${ }^{3}$, Sultana $\mathrm{Z}^{4}$
}

\begin{abstract}
The uterus is an essential principal accessory female reproductive organ whose function is to receiving and rearing an egg within its mucosa, nourishes and protects the embryo, and expels it at the proper time. Uterus related clinical conditions such as leiomyomas also known as myomas or fibroid and carcinoma cervix are major medical conditions within aging population. Detailed morphological knowledge is essential for proper diagnosis and management of uterine diseases.
\end{abstract}

Study design was descriptive type of study.

Place and period of study was department of anatomy, Sylhet M A G Osmani Medical College, Sylhet, from July 2006 to June 2007.

Present study was performed on 50 autopsied human uterus of age ranging from 1 to 65 years. The samples were collected from unclaimed dead bodies that were autopsied in the morgue of Department of Forensic Medicine of Sylhet M A G Osmani Medical College, Sylhet.

The samples were divided into four age groups. Group A (1-12 years), Group B (13-24 years), Group C (25-46 years) and Group D (46-65 years). All samples were studied morphologically.

Statistically significant positive correlation was found between age breadth and thickness of uterus.

There were changes in the morphology of uterus in relation to age.

Key words: Uterus, Breadth \& Thickness.

\section{Introduction}

The uterus is an essential principal accessory female reproductive organ whose function is to receiving and rearing an egg within its mucosa, nourishes and protects the embryo, and expels it at the proper time ${ }^{1}$.

1. Corresponding Author: Dr. Md. Samir Uddin Assistant Professor, Department of Anatomy Sylhet Women's Medical College, Sylhet Email:dr.samir69@gmail.com

2. Dr. Mohammed Al- Muhaimin Assistant professor, Department of Anatomy Sylhet Women's Medical College, Sylhet

3. Dr.Nazma Begum

Associate Professor, Department of Anatomy Sylhet MAG Osmani Medical College, Sylhet

4. Professor Dr. Zakia Sultana

Professor \& Head, Department of Anatomy

Sylhet M.A.G Osmani Medical College, Sylhet
The uterus-a thick walled, pear shaped, hollow muscular organ-lies in the lesser pelvis normally with its body lying on the top of the urinary bladder and its neck (cervix) between the urinary bladder and rectum ${ }^{2}$.

Benign tumors and tumor-like conditions occur more commonly in the uterus than perhaps in any other organ. Neoplasm's of the uterus are all leiomyomas ${ }^{3}$ which may be found in nearly one woman in three over the age of 30 years. These are also among the commonest large solid benign neoplasm, being exceeded in size only by giant lipomas ${ }^{4}$. These benign tumours arise from the uterine myometrium or, less commonly from the cervix. They are composed not only of smooth muscle but of various amounts of elastin, collagen and extra cellular matrix proteins.

Endometrial carcinoma is the most common malignancy of the female genital tract, accounting for almost one half of all gynecologic cancers in the United States. In 2006, an estimated 41, 200 new cases and 7, 350 cancer-related death are anticipated. Endometrial carcinoma is the fourth most common cancer, ranking behind breast, lung, and bowel cancer and the eighth leading cause of death from malignancy in woman. Overall about $2 \%$ to $3 \%$ of woman develop endometrial cancer during their life time ${ }^{5}$.

The morbidity and mortality associated with uterine diseases affect an increasing number of women and is a major medical condition within our aging population. Disease can be defined and measured only in terms of deviation from normal structure and function. A clear conception on the anatomy of uterus is a prerequisite for the diagnosis and treatment of uterine diseases.

The situation in developing countries like Bangladesh is more gloomy. There is no adequate data regarding the above mentioned diseases. So considering the above aspects, investigation regarding anatomical changes of the uterus in relation to age may lead to valuable information which may cause some modification in both medical and surgical treatment of uterine disorders.

\section{Materials and Methods}

The samples of human uterus were collected from unclaimed dead bodies that were under examination in the morgue of the department of forensic Medicine of Sylhet M.A.G Osmani Medical College from September 2006 to March 2007. Following legal formalities the samples were collected within 24-36 hours of death without any sign of putrefaction. All the samples were collected from medicolegal cases. During collection appropriate age and cause of death were noted from morgue's record. The samples were brought to the department of Anatomy, Sylhet 
M.A.G Osmani Medical College. The samples were tagged immediately, which was bearing a code number for subsequent idendification. Soon after collection each sample was gently washed in tap water on a dissection tray. Blood and blood clots were removed as per as possible. Then the samples were fixed in $10 \%$ formol saline solution. The collected samples were divided into four groups.

Table -1: Age distribution in different group

\begin{tabular}{ccc}
\hline Group Age & Age limit(Years) & No of samples \\
\hline A & $1-12$ & 7 \\
B & $13-24$ & 15 \\
C & $25-45$ & 19 \\
D & $46-65$ & 9 \\
\hline
\end{tabular}

Variable studied

$$
\begin{aligned}
& \text { 1. } \quad \text { Breadth of uterus } \\
& \text { 2. Thickness of uterus }
\end{aligned}
$$

Measurement procedure:

1. Breadth of the uterus: The breadth was measured at the region of its highest transverse diameter; usually it was below the opening of the uterine tube into uterus. Measurement was done with the help of a slide caliper graduated in $\mathrm{cm}$.

2. Thickness of the uterus: Thickness was measured at the region of the middle of the corpus uteri. Measurement was done with the help of a slide caliper graduated in $\mathrm{cm}$.

\section{Result}

\section{Breadth of the uterus:}

The mean \pm SD breadth of the uterus was was $2.94 \pm 0.48$ $\mathrm{cm}$, in group A (1-12 years), $4.34 \pm .44 \mathrm{~cm}$ in group B(1324 years $), 4.89 \pm 0.34 \mathrm{~cm}$ in group $\mathrm{C}(25-45$ years $)$ and 3.13 $\pm 0.31 \mathrm{~cm}$ in group D (46-65years).

The highest mean breadth was found in group $\mathrm{C}$ and the lowest mean breadth was found in group A. The mean difference in breadth between the four groups were significant $(\mathrm{p}<0.001)$ positive correlation was present between age and breadth of the uterus $(\mathrm{r}=+0.199 \mathrm{p}<0.001)$ (Table II, Fig 1 \& 2).

Table- 2 : Breadth and Thickness of uterus in different study group

\begin{tabular}{ccc}
\hline $\begin{array}{c}\text { Group } \\
(\mathbf{n})\end{array}$ & $\begin{array}{c}\text { Breadth(in cm) } \\
\text { mean } \pm \text { SD } \\
\text { (range) }\end{array}$ & $\begin{array}{c}\text { Thickness(in cm) } \\
\text { mean } \pm \text { SD } \\
\text { (range }\end{array}$ \\
\hline A & $2.94 \pm 0.48$ & $1.08 \pm 0.22$ \\
$(7)$ & $(2.1-3.6)$ & $(0.78-1.36)$ \\
B & $4.34 \pm 0.44$ & $2.51 \pm 0.25$ \\
$(15)$ & $(3.2-5.2)$ & $(1.85-3.20)$ \\
C & $4.89 \pm 0.34$ & $3.13 \pm 0.31$ \\
$(19)$ & $(3.9-5.6)$ & $(2.42-3.68)$ \\
D & $3.13 \pm 0.31$ & $2.29 \pm 0.34$ \\
$(9)$ & $(3.6-4.1)$ & $(0.75-2.94)$ \\
\hline
\end{tabular}

\begin{tabular}{ll} 
& P value \\
\hline A vs B & $<0.001^{* * *}$ \\
B vs C & $<0.05^{*}$ \\
C vs D & $<0.001^{* * *}$ \\
A vs D & $<0.001 * * *$ \\
\hline
\end{tabular}

Group A : Age 1-12 years

Group B : Age 13-24 years

Group C : Age 25-45 years

Group D : Age 46 -65 years

$\mathrm{SD}=$ Standard deviation

$* * *=$ Significant

(In unpaired Student's 't'test of significance of difference between groups)

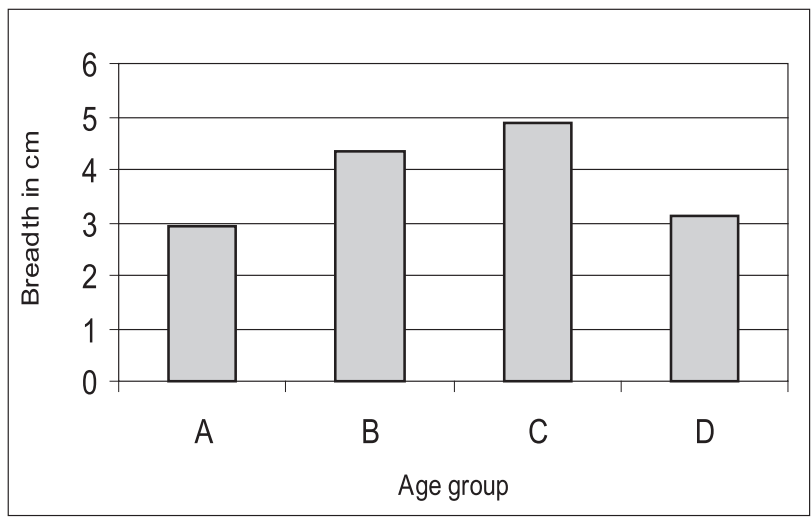

Fig 1: Breadth of the uterus in different age groups

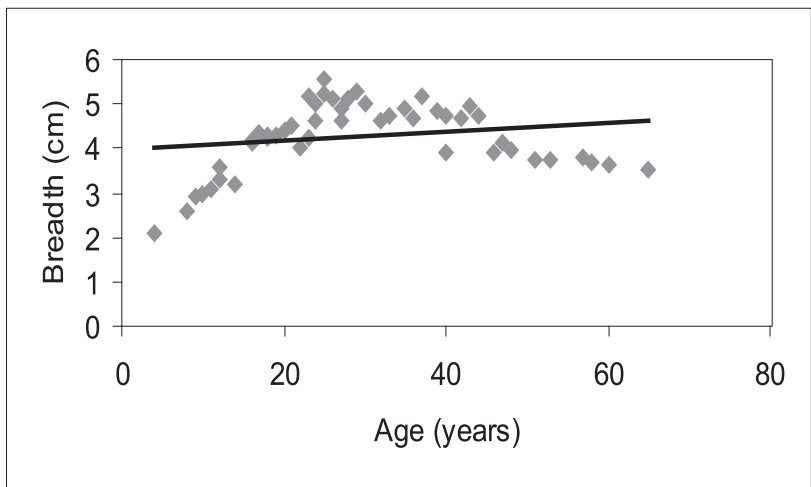

Fig: 2. Relationship between age and breadth $(n=50)$

Thickness of the uterus:

The mean \pm SD thickness of the uterus was was $1.08 \pm 0.22$ $\mathrm{cm}$, in group A (1-12 years), $2.51 \pm 0.25 \mathrm{~cm}$ in group $\mathrm{B}(13$ 24 years), $3.13 \pm 0.31 \mathrm{~cm}$ in group $\mathrm{C}$ (25-45 years) and 2.29 $\pm 0.34 \mathrm{~cm}$ in group D (46-65years).

The highest mean thickness was found in group $\mathrm{C}$ and the lowest mean thickness was found in group A. The mean difference in thickness between the four groups were significant $(\mathrm{p}<0.001)$ positive correlation was present between age and thickness of the uterus $(r=+0.302 \mathrm{p}<0.001)$ (Table II , Fig 3 \& 4). 


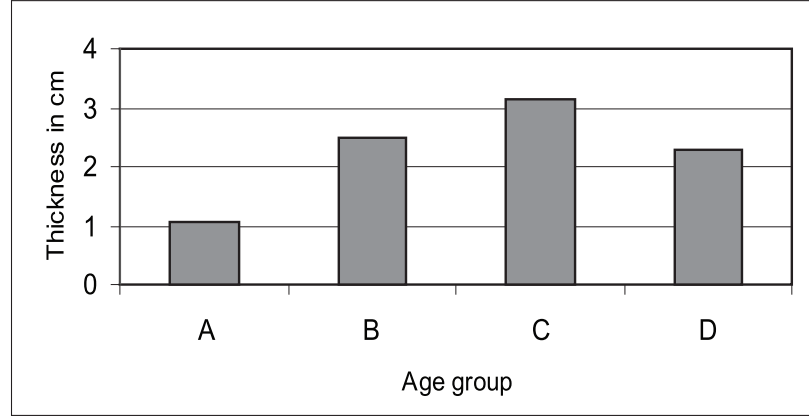

Fig 3: Thickness of the uterus in different age groups

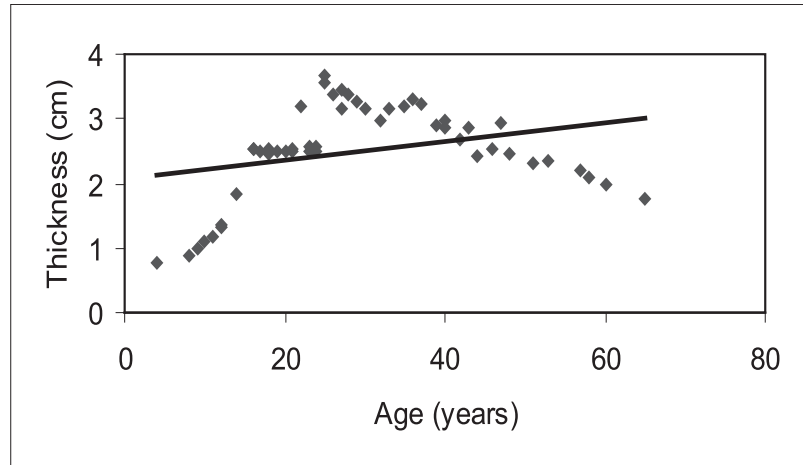

Fig 4: Relationship between age and thickness $(n=50)$

\section{Discussion}

Breath of the uterus:

Breadth of the uterus described by Sinnatamby ${ }^{7}$ and Snel $^{8}$ $5 \mathrm{~cm}$ Jeffcoat's ${ }^{9} 6 \mathrm{~cm}$. Bloomand Creisheimer ${ }^{10} 3.5 \mathrm{~cm}$.

The average breadth of the uterus in group $\mathrm{A}$ was less than that of group B and $\mathrm{C}$. The maximum value was found in group C. In group D the breadth decreased due to atrophy.

Hossain ${ }^{6}$ studied 40 human postmortem uterus of different age groups and found the average mean breadth of uterus were $($ mean $\pm \mathrm{SE}) 2.22 \pm 0.23 \mathrm{~cm}$ from 1 to 12 years age group, $4.15 \pm 0.23 \mathrm{~cm}$ from 13 to 24 years age group, 4.38 $\pm 0.13 \mathrm{~cm}$ from 25 to 45 years age group, $3.76 \pm 0.17 \mathrm{~cm}$ from 45 to 65 age group.

So the findings of the present study are similar to the findings of Hossain ${ }^{6}$ but the values were little less than the above mentioned author and it may be due to racial variation and was also somewhat shrinkage due to fixation.

Thickness of the uterus:

Thickness of the uterus described by Moore and Dalley ${ }^{2}$ $2 \mathrm{~cm}$ Sinnatamby ${ }^{7} 3 \mathrm{~cm}$. Snel ${ }^{8}$ and Woodburne $\mathrm{T}^{11} 2.5 \mathrm{~cm}$. $\mathrm{Ham}^{12} 1.5 \mathrm{~cm}$ to a slightly less than $1 \mathrm{~cm}$. and Hamilton ${ }^{13} 3$ $4 \mathrm{~cm}$.

Hossain ${ }^{6}$ studied 40 human postmortem uterus of different age groups and found the average mean thickness of uterus were (mean \pm SE) $.95 \pm 0.10 \mathrm{~cm}$ from 1 to 12 years age group, $2.52 \pm 0.18 \mathrm{~cm}$ from 13 to 24 years age group, 2.98 $\pm 0.13 \mathrm{~cm}$ from 25 to 45 years age group, $2.43 \pm 0.19 \mathrm{~cm}$ from 45 to 65 age group.
So the findings of the present study are similar to the findings of Hossain ${ }^{6}$

In group A, thickness of the uterus was minimum due to hormonal influences. The overall size of the uterus increases after that which resulted increase in thickness of the uterus. The maximum thickness was found in group C. It can be explained not only by the longer duration of hormones but also by the number of pregnancies. In the postmenopausal group D, thickness of the uterus decreased due to lack of hormonal stimulation. In the present study the average thickness of the uterus was almost similar to the findings of the above mentioned authors.

\section{References:}

1. Arey LB. Developmental anatomy. A text book and laboratory manual of embryology. 7th ed. Philadelphia: WB Saunders Company; 1966;315-19.

2. Moore KL, Dalley AF II. Clinically oriented Anatomy. 4th ed. Baltimore: Lippincott Williams and Wilkins; 1999;374-82.

3. Cramer S.F and Patel A. The frequency of uterine leiomyomas. Am J Clini Pathol. 1990;94:435-38.

4. D. Keith editor. Dewhurst's textbook of Obstetrics and Gynecology for postgraduates. 6th ed. Blackwell Science; 2000;552

5. Berek \& Novak's, editor. Gynecology. 14th ed. New Delhi: Lippincott Williams \& Wilkins; 2007;1343.

6. Hossain A. An anatomical study of age related histomorphological changes in postmortem human uterus in Bangladesh (M. Phil Thesis).Dhaka: University of Dhaka; 1992

7. Sinnatamby CS. Last's anatomy: regional and applied. 10th ed. Edinburgh: Churchill Livingstone; 2001;29396.

8. Snell RS. Clinical anatomy for medical students. 7th ed. Philadelphia: Lippincott Williams and Wilkins; 2004;392-96.

9. Bhatla N. Jeffcoate's Principles of Gynaecology. 6th ed. London: Arnold hodler group; 2001;72-78.

10. Creisheimer EM, Wiedeman MP. Anatomy \& Physiology, 9th ed. Philadelphia:J.B. Lippincott Company; 1972;593 - 99.

11. Woodburne RT. Essentials of human anatomy, 5 th ed. New York: Oxford University Press; 1973;494-97.

12. Ham Aw, Cormack DH. Histology. 6th ed. Philadelphia:J.B. Lippincott Company; 1979;899-06.

13. Hamilton WJ, editor. Textbook of human anatomy, 2nd ed. London: The Macmillan Press Ltd; 1976;444-53. 